The Effect of Deposit Insurance on Market Discipline:

Evidence from a Natural Experiment on Deposit Flows

by

\author{
Alexei Karas, Roosevelt Academy \\ William Pyle, Middlebury College \\ Koen Schoors, CERISE, Ghent University
}

July, 2009

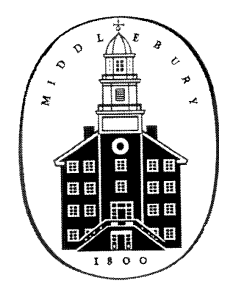

DEPARTMENT OF ECONOMICS

MIDDLEBURY COLLEGE

MIDDLEBURY, VERMONT 05753

http://www.middlebury.edu/ econ 


\title{
The Effect of Deposit Insurance on Market Discipline: Evidence from a Natural Experiment on Deposit Flows
}

\author{
Alexei Karas, Roosevelt Academy \\ William Pyle, Middlebury College \\ Koen Schoors, CERISE, Ghent University
}

July, 2009

\begin{abstract}
We explore how the introduction of explicit deposit insurance affects deposit flows into and out of banks of varying risk levels. Using evidence from a natural experiment in Russia, we employ a difference-in-difference estimator to isolate the change in the deposit flows of the newly insured group (i.e., households) relative to the uninsured "control" group (i.e., firms), thus improving upon prior studies that have sought to identify the effect of deposit insurance on market discipline. We find that the relative sensitivity of household deposits to bank capitalization diminished markedly after the introduction of an insurance program covering their deposits but not those of firms. The finding, we demonstrate, is not an artifact of the two groups responding differently to a banking crisis that occurred in Russia at roughly the same time.
\end{abstract}




\section{The Effect of Deposit Insurance on Market Discipline:}

\section{Evidence from a Natural Experiment on Deposit Flows}

\section{Introduction}

A particular challenge facing the architects of modern financial safety nets lies in the possibility that measures taken to mitigate bank failures might also weaken other forces contributing to banking sector stability (Calomiris, 1999). The introduction of explicit deposit insurance presents just such a dilemma. Its potential for stabilizing economies by limiting bank runs helps explain its ubiquity across OECD countries and its spread in recent years to remote corners of the developing world (Demirguc-Kunt and Kane, 2002). ${ }^{1}$ But if depositors are made numb to the consequences of institutional failure, the disincentives of their banks to engage in excessive risk-taking may weaken. The downside of deposit insurance, that is, may lie in the consequences of decreased market discipline.

The degree to which depositors actually engage in market discipline and the extent to which such behavior is actually curtailed by explicit deposit insurance are questions that must be resolved empirically. The data available to previous studies, however, have made it difficult for researchers to cleanly identify the effect of deposit insurance. Most published studies rely upon comparisons of uninsured and insured depositors and attribute behavioral differences to the impact of insurance. But their approach is open to criticism that other characteristics, which may vary across depositor groups, explain the observed differences in behavior. A smaller number of studies infer the impact of deposit insurance on market discipline by comparing the behavior of a well-defined group before and after the introduction of deposit insurance. This approach, however, cannot dismiss the possibility that results are driven by time-specific factors other than the introduction of insurance.

We are fortunate to have at our disposal data from what effectively amounts to a natural experiment. In a manner unique to the literature, we can thus explore whether and how the introduction of explicit deposit insurance affects deposit flows into and out of banks of varying risk levels. In 2004, a comprehensive deposit insurance scheme was introduced to cover all household deposits in Russian banks. Deposits of firms, however, were left uncovered. Since our bank-level data report these two categories separately and cover the periods preceding and following the scheme's introduction, we can apply a difference-in-difference estimator to identify the effect of the policy on households. Using firm deposits as a benchmark, that is, we filter out from any post-deposit-insurance change in household deposits the effect of any time-specific factors that would influence the

1 The United States introduced the first national system of deposit insurance in 1934. Recent years have witnessed a particularly rapid expansion in its use. In 1995, 49 countries offered explicit deposit insurance; by 2003, this number had grown to 87 (Demirguc-Kunt, Kane and Laeven, 2008). 
behavior of all depositors in a similar manner. Our results demonstrate a noteworthy reduction in the relative disciplining behavior of households, a finding consistent with deposit insurance having had a direct effect on market discipline.

We consider the possibility that our finding might be explained in part or in whole by a time-specific factor that had a differential impact on the two depositor groups. In 2004, at roughly the same time that deposit insurance was introduced, Russia was hit by a small banking crisis. And prior research suggests that banking crises may have a direct effect on market discipline by providing a "wake-up call" to depositors, alerting them anew to the potential for bank insolvency (Martinez-Peria and Schmukler, 2001). In the interests of cleanly identifying the effect of deposit insurance, we compare the relative market disciplining behavior of firms and households in the aftermath of both this crisis and a previous one in 1998. After the 1998 crisis, both households and firms demonstrate comparable increases in market discipline, evidence consistent with the "wake-up call" effect. After the 2004 crisis, however, the uninsured firms increase market discipline but the newly insured households do not. The difference in relative disciplining behaviors across crises, we argue, arises from the direct effect of deposit insurance after 2004.

Our findings thus make two noteworthy contributions to the literature on market discipline and deposit insurance. First, the data allow us to carry out what we believe to be the cleanest test heretofore of the direct impact of deposit insurance on market discipline. In so doing, we also contribute to research that implicitly assumes a relationship between deposit insurance and market discipline and explores downstream linkages in a potential causal chain leading from deposit insurance to banking crises - e.g., between market discipline and bank risk (Nier and Baumann, 2006), between deposit insurance and bank risk (Ioannidou and Penas, 2008), and between deposit insurance and banking crises (Demirguc-Kunt and Detragiache, 2002).

Second, we contribute to the literature on the effect of banking crises on market discipline through a comparison of the behaviors of insured and uninsured depositors. Since, as has been the case with the recent global downturn, explicit deposit insurance programs are often introduced or expanded during periods of financial crisis (DemirgucKunt, Kane and Laeven, 2008), understanding the interaction of crises and deposit insurance on subsequent market disciplining behavior can be of particular value to those designing financial market institutions.

Our article is organized as follows. Section 2 reviews prior research on the relationship between deposit insurance and deposit-market discipline and the downstream effects of both on bank risk and financial crises. Section 3 reviews the relevant histories of deposit markets and deposit insurance in Russia. Sections 4 and 5, respectively, introduce our data and methodological approach for identifying the effect of deposit insurance on market discipline. Section 6 presents our results and section 7 presents an extended robustness check in which we expand the time-period of our analysis in order to compare the effects of the 1998 and 2004 crises. Section 8 offers concluding thoughts. 


\section{Deposit Insurance, Market Discipline and Bank Risk}

Market discipline requires that depositors both have access to information on bank risk and anticipate bearing a cost in the event of bank insolvency. Researchers first began looking for evidence of market discipline where these conditions appeared to be most clearly met - in uninsured niches of markets with a well-developed informational infrastructure. Investigating partially uninsured large deposits in the United States, Park and Peristiani (1998) demonstrated a negative relationship between thrifts' predicted probability of failure and the subsequent growth of their large uninsured deposits. Others turned up links between U.S. institutions' cost of funds in one period and their prior-period measures of depositor risk: low capital-assets ratios; high variability of return on assets; higher percentages of bad loans and, generally, lower return on assets; and greater exposure to junk bonds (Brewer and Mondschean, 1994; Hannan and Hanweck, 1988; Park and Peristiani, 1998).

Among this first generation of articles, the one by Park and Peristiani (1998) stands out for comparing the propensity of uninsured and insured depositors in providing market discipline. ${ }^{2}$ Given the latter's potential interest in monitoring the behavior of their banks as well, this comparison provides a better sense - than an exclusive focus on the uninsured of how the introduction of explicit insurance affects disciplining behavior. Indeed, these authors find that measures of risk have an adverse effect on the growth and pricing of smaller deposits that were insured, although to a lesser extent than on the deposits that were larger and thus partially uninsured. The difference in disciplining behavior is attributed implicitly to the introduction of deposit insurance.

Analyzing the behavior of smaller insured and larger uninsured deposits in Argentina and Chile, Martinez-Peria and Schmukler (2001) explicitly present the comparison as a test of deposit insurance's effect on market discipline. They find that both types of deposits are sensitive to bank risk. But unlike Park and Peristiani (1998), they uncover little discernible difference between the two depositor types' disciplining behaviors. Explicit deposit insurance, that is, seems to have had little to no effect in these Latin American countries. The protection schemes, the researchers conjecture, were not viewed as credible.

As a test of the effect of explicit deposit insurance on market disciplining behavior, however, the approach adopted by Park and Peristiani (1998) and Martinez-Peria and Schmukler (2001) presents problems. Notably, small insured depositors may be different from the large un-insured depositors in ways that cannot be observed but that are conceivably related to market discipline. Larger depositors, for instance, may be more risk averse or more informed about bank fundamentals than small depositors. As a result, the

\footnotetext{
2 Insured depositors may feel compelled to monitor their banks if the insurer's guarantee is not ironclad or if they face a cost to recovering funds from a failed institution. Cook and Spellman (1994) show that deposits at institutions insured by the Federal Savings and Loan Insurance Corporation were sensitive to risk measures, such as the leverage ratio, during a period when the guarantor had been declared insolvent.
} 
comparison of these groups' contemporaneous behavior does not inform us as to how the introduction of an explicit insurance scheme is likely to affect the propensity of a given group of depositors to engage in market discipline.

Another approach that has been taken to infer the effect of deposit insurance on market discipline exploits comprehensive bank-level data and a recently compiled crosscountry dataset of deposit insurance policies. Controlling for the presence of explicit insurance in a sample of thirty OECD and developing countries from 1990-1997, DemirgüçKunt and Huizinga (2004) uncover a negative relationship between the implicit cost of bank funds and prior period measures of bank capitalization, profitability and liquidity. Moreover, they demonstrate that explicit deposit insurance significantly reduces interest sensitivity to these measures of bank risk. In deposit growth regressions on a larger group of countries, better capitalized banks are found to be more successful in attracting deposits. But in the presence of explicit deposit insurance, this relationship is muted, a result consistent with weaker market discipline. As with within-country comparisons of insured and uninsured depositors (Park and Peristiani, 1998; Martinez-Peria and Schmukler, 2001), this cross-country approach - which covers a period in which only two of the countries in the sample introduced explicit deposit insurance - relies on inferring the marketdisciplining effect of explicit deposit insurance from a potentially diverse group of depositors. Depositors in countries that already have explicit deposit insurance may be fundamentally different on average from those in countries in which it has not been introduced. It is even possible that a country's policy with respect to deposit insurance is endogenous to the behavioral predispositions of its depositors.

To avoid drawing conclusions from a comparison of fundamentally different depositor groups, a test for the effect of deposit insurance on market discipline should be based on a "before-and-after" perspective. For a given group of depositors, that is, we would like to compare their behavior both prior to and after an explicit insurance scheme's introduction. An un-published study by Ioannidou and de Dreu (2006), using Bolivian data from 1998-2003, finds that the magnitude of the coefficients designed to proxy for market discipline shrink notably after the introduction of explicit deposit insurance in 2001. By providing a "before-and-after" comparison for a specific group of depositors, their approach provides more direct evidence of deposit insurance's effect on market discipline than prior studies. However, they cannot fully control for time-varying, macro-level factors that may have an influence on market discipline. Their study thus cannot rule out the possibility that the apparent post-deposit-insurance reduction in market discipline is at least partly (if not wholly) the result of some unobserved macro-level factor confined either to the pre- or post-insurance period.

Recognizing a potential causal chain from the introduction of deposit insurance to the reduction of market discipline to an increase in bank moral hazard to an increase in banking sector instability, a related literature effectively assumes the first link and looks for 
evidence of the expected relationships between other links. ${ }^{3}$ Nier and Baumann (2006) demonstrate that banks more prone to be disciplined - because they might rely more on uninsured liabilities or because they face greater disclosure requirements - carry larger capital buffers and are thus inherently more stable. And Ioannidou and Penas (2008) show that Bolivian banks were more likely to initiate riskier loans after the introduction of deposit insurance. And in a cross-country study similar in spirit to Demirgüç-Kunt and Huizinga (2004), Demirguc-Kunt and Detragiache (2002), find that generous insurance schemes are related to a greater likelihood of banking crises, particularly in weak rule of law environments. ${ }^{4}$

\section{Deposit Markets and Deposit Insurance in Russia}

Dating back less than two decades, the experience with liberalized deposit markets in Russia has been relatively brief. ${ }^{5}$ Indeed, this relatively short period in which to develop institutions that facilitate depositor monitoring probably explains why Barth et al. (2004, 2006) ranked Russia in the bottom quintile of over one hundred countries on a "private sector monitoring" (PSM) index, a measure meant to capture the quality of institutions that facilitate deposit market discipline. ${ }^{6}$ Although the ranking raises questions about Russian depositors' ability to monitor and discipline banks, it does not provide any sense of their interest in doing so. However, a review of Russia's post-communist financial sector development suggests that the intensity of this interest should not be under-estimated.

\footnotetext{
${ }^{3}$ Exploring causation in the opposite direction Demirguc-Kunt, Kane and Laeven (2008) use crosscountry panel data to demonstrate that countries experiencing banking crises are more likely to introduce deposit insurance.

${ }^{4}$ Gropp and Vesala (2004) lay out a model, with corroborating evidence from the European Union, suggesting a policy of explicit insurance acts as a commitment device to limit coverage only to those parties explicitly covered. By thus increasing monitoring incentives of parties that may have otherwise considered themselves implicitly insured, explicit insurance may actually reduce moral hazard.

5 The first part of this section draws on a similar discussion in Karas et al. (2009).

${ }^{6}$ The following considerations are factored positively into a country's score on the PSM index: (1) whether a certified external audit of the bank's financial statement is required; (2) whether all of the ten biggest banks are rated by international rating agencies; (3) whether income statements include accrued or unpaid interest or principal on non-performing loans and whether banks are required to produce consolidated financial statements; (4) whether off-balance sheet items are disclosed to the public; (5) whether banks must disclose risk management procedures to the public; and (6) whether subordinated debt is allowable as a part of regulatory capital. The version of the PSM index presented in Barth et al. (2006) is slightly modified to include the percentage of the ten biggest banks rated by domestic rating agencies; since there is no entry for Russia in this sub-category, its PSM index is not reported. The authors' measures of bank transparency paint a similar picture. With respect to both the quality of its bank audit regime and its pace in adopting best practice accounting standards, Russia is ranked in the bottom third of countries surveyed.
} 
When financial markets were first permitted in the early 1990s, bank deposits, particularly those of households, were held almost exclusively by Sberbank, the state-owned savings bank. But lax entry policies in the early post-communist period contributed to the quick development of a relatively competitive market for deposits. By 1994, private banks had captured over half of the household deposit market. The mix of liberalized deposit rates, naïve depositors and over-burdened regulators proved volatile. System-wide crises, including a particularly large one in 1998, led to the insolvency of many of the largest banks on the retail market during the first decade of post-communist reform. Obligations to tens of thousands of depositors went unmet (Perotti, 2003; Radaev, 2000; Schoors, 2001; Spicer and Pyle, 2002). These experiences quickly heightened Russians' awareness of the private costs of bank failure and thus the value of carefully monitoring their financial institutions.

In Karas et al. (forthcoming), we demonstrate that in the half decade after the 1998 crisis, but before the introduction of explicit deposit insurance, market discipline in Russia had become fairly sophisticated. Flows of household and firm deposits during this period were consistent with quantity-based sanctioning of weaker banks; more poorly capitalized banks, that is, were less successful in attracting the deposits of households and firms. But evidence for the standard form of price discipline (i.e., depositors requiring a deposit rate premium from less stable banks) was weak. ${ }^{7}$ This combination of findings, we argued, would be consistent with households and firms interpreting the deposit rate as a complementary proxy of otherwise unobserved bank-level risk. Testing this hypothesis, we estimated the deposit supply function and showed that, particularly for poorly capitalized banks, deposit rate increases exhibited diminishing, and eventually negative, returns in terms of deposit attraction. The deposit supply curve, in other words, is backward bending. ${ }^{8}$

Russia's Deposit Insurance Agency (DIA) was created as an independent agency in January 2004 and given responsibility for administering the national deposit insurance fund. The DIA was charged with determining bank premiums, making any necessary payouts to depositors and overseeing the liquidation of insolvent banks. ${ }^{9}$ The Russian government provided initial seed capital but premiums - payable quarterly and assessed on the daily averages of a bank's insured deposits - quickly became the fund's primary source of financing. The deposits of households, but not firms, were to be covered. And all private banks that accepted household deposits were required to participate. All deposits up to 100,000 rubles were fully insured from when banks were first admitted into the system in

7 Ungan et al. (2008) presented similar findings from a slightly later period.

${ }^{8} \mathrm{~A}$ recent geographically representative survey of 1600 Russians asked "At what annualized interest rate would you refuse to deposit money in a bank because of suspicions as to its stability?" Russians' median response of $24.5 \%$ turned out to be quite comparable to the $6 \%$ quarterly (real) rate at which we estimated the deposit supply curve began bending backward (“What deposit rate?" 2008).

9 The DIA's board includes seven government-appointed representatives in addition to five representatives from the Central Bank of Russia. 
September 2004 until August 2006. From then until March 2007, up to 190,000 rubles per deposit were insured, with amounts above 100,000 insured at a $90 \%$ rate (Camara and Montes-Negret, 2006). ${ }^{10}$

By January 1, 2005, several month's into the system's operation, 829 banks and a bit more than 330,000 deposit accounts, with an average deposit size of seven thousand rubles (roughly \$252), were insured by the system. Of these accounts, 98.5\% were under 100,000 rubles and thus fully insured. Two years later, 934 banks and roughly 366,000 deposit accounts, with an average deposit size of twelve thousand rubles (roughly \$455) were covered by the program. Of these, $99.6 \%$ held deposits under 190,000 rubles and thus were insured at a rate of at least $95.3 \% .{ }^{11}$ Generally, it has been the case that since the introduction of deposit insurance, we have observed particularly rapid growth in personal deposits, much of which has been accounted for by term deposits with maturities between half a year and three years. Sberbank's market share, moreover, declined after household deposits became insured. There has also been a decline in the combined market share of the thirty largest banks, suggesting that the insurance scheme has contributed to greater competition within the retail banking market (Camara and Montes-Negret, 2006; Chernykh and Cole, 2008).

Russia was struck by a small banking crisis during the spring and summer of $2004 .{ }^{12}$ In response, Russia's State Duma swiftly modified the arrangements governing deposit insurance (Tompson, 2004). Household deposits with failed institutions that were outside the deposit insurance system would be temporarily covered for sums of up to 100,000 rubles. In other words, from the middle of July 2004, all household deposits were covered by temporary insurance (Federal Law No. 96-FZ). ${ }^{13}$ This emergency coverage was subsequently replaced by that from the general deposit insurance program for those banks that were admitted. Banks not admitted to the general program lost the rights to attract new

${ }^{10}$ Ruble equivalents in dollar deposits were also covered. The insured maximum was raised again at the end of March 2007 but that period falls outside of our analysis here.

${ }^{11}$ These data, and updates, can be accessed at www.asv.org.ru, the website of the Deposit Insurance Agency.

${ }^{12}$ In May 2004, after the licenses of a couple of small banks were withdrawn on charges of money laundering and failure to comply with prudential regulations, rumors began to circulate of a CBR blacklist of weak banks, which was reported to include larger institutions. These led to a rush of deposit withdrawals and growing liquidity problems at a number of banks. In July, one of Russia's largest retail banks collapsed, fueling rumors that Alfa Bank, the largest private retail bank, would be next. Panicked depositors withdrew $\$ 160$ million in deposits (12\% of total) from Alfa Bank in a three day period. Rapid policy responses of the CBR and the State Duma prevented a further deterioration of the situation and the panic abated. Private deposits in the banking system started to grow again shortly thereafter (Camara and Montes-Negret, 2006)

${ }^{13}$ Such a policy of blanket deposit guarantees has become common in the midst of systemic banking problems around the world (Demirguc-Kunt, Kane and Laeven, 2008) as demonstrated most recently in the responses of many countries to the global financial crisis of 2008-09. 
household deposits and renew existing deposit contracts, thus leading to a progressive deterioration in their household deposit base.

\section{Data}

All Russian banks are required to disclose their financial statements to the Central Bank of Russia (CBR). This information is then made available to the public through several channels. Since 1999 an increasing number of banks granted the CBR permission to disclose their detailed balance sheets and income statements online via the CBR's website (http://www.cbr.ru/credit/transparent.asp). Less detailed bank balances but for all Russian banks are provided since 1998 by a private information agency Banksrate.ru at www.banksrate.ru. Further, banks publish their balances in the financial press such as the monthly financial periodical Den'gi $i$ Kredit. Finally, the most detailed information on all Russian banks can be purchased from private information agencies.

The data used in the analysis in sections 6 and 7 was made available to the authors by two respected private financial information agencies, Interfax and Mobile, and consists of quarterly bank balances of all Russian banks from 1995q4 through 2007q1. ${ }^{14}$ The panel of banks is unbalanced because some banks fail, some merge, and some are founded during the sample period. If a bank acquired or merged with another bank, we treat the resulting larger bank as "new" from the standpoint of our sample.

We have separate measures of a bank's household and firm deposits and employ them both as dependent variables in a manner that is critical to our identification strategy. The two depositor types, as we explained, are treated differently under Russia's deposit insurance scheme. But we should also be sensitive to the possibility that, independent of deposit insurance, the two may differ in their willingness and/or ability to discipline deposit-taking institutions (Karas et al., forthcoming). Enterprise managers, for instance, might have better access to or more appreciation for the financial information released by banks. Or they might face a different set of costs in transitioning their deposits between banks.

We measure a bank's risk level through its capital-assets ratio. Models of bank behavior have long treated this measure of leverage as directly related to default risk (Merton, 1977). More practically, in the wake of the 1988 Basel Accord and the 1996 Market Risk Amendment, banks have increasingly relied upon capital adjustments as the channel through which to manage the threat of insolvency (Nier and Baumann, 2006). Further, more than any other measure, it has been used to proxy for risk exposure in prior studies of deposit-market discipline (Cook and Spellman, 1994; Hannan and Hanweck, 1988; Park and Peristiani, 1998; Martinez-Peria and Schmukler, 2001; Demirgüç-Kunt and Huizinga, 2004; Karas et al., forthcoming).

${ }^{14}$ For more information on these firms, see their respective websites at www.interfax.ru and www.mobile.ru. Karas and Schoors (2005) provide a detailed description of the datasets and confirm the consistency of different data sources. 
As an alternative measure of bank stability, we use its current liquidity ratio - i.e., the sum of its liquid assets divided by the sum of its liabilities on demand accounts and accounts up to 30 days. In general, one might expect it to have the same effect as capitalization with respect to market discipline. Highly liquid banks, that is, should be better able to accommodate unexpected deposit withdrawals (Martinez-Peria and Schmukler, 2001; Demirguc-Kunt and Huizing, 2004).

Since depositors are hypothesized to react to observable data, these simple measures of bank-level stability both have the appealing characteristic that they can be easily calculated by using publicly available information. Other, more sophisticated measures suggested in the literature could either not be constructed from the available data or do not exist on a comprehensive basis (e.g., bank ratings) over the sample period. ${ }^{15}$

Our analysis is limited to private banks participating in the deposit insurance program. We exclude all state-owned banks, many of which have consistently enjoyed advantages over their private competitors: privileged access to state funds, de facto exemption from some regulations and explicit backing for their retail deposits during the entirety of the period covered by our data (Tompson, 2004; Civil Code of Russia, article 840). ${ }^{16}$ Banks not admitted to the deposit insurance program are excluded from our analysis since they were ultimately banned from attracting new household deposits and forbidden from renewing existing contracts. Analysis in section 6 starts from the first quarter of 1999 and concludes with the first quarter of 2007. We use the fourth quarter of 2004 as the first post-deposit-insurance observation.

Corresponding with a period of rapid economic expansion in Russia, the summary statistics from our sample banks in Table 1 reveal robust quarterly deposit growth rates both before and after the introduction of deposit insurance. ${ }^{17}$ After 2004, deposits of both firms and households continued to grow but at slightly reduced rates in nominal terms. As a share of total banking assets, household deposits increased greatly after the introduction of deposit insurance, rising from $13 \%$ to $25 \%$. Over the same period, firm deposits as a share of bank assets remained quite stable.

\section{[Table 1]}

\footnotetext{
${ }^{15}$ Van Soest et al. (2003) report that in October 2001 Fitch IBCA published ratings for only 15 Russian banks while Moody's and Standard \& Poor's did so for even fewer banks. Russian rating agencies provided ratings for up to a hundred banks but that data is not readily available.

${ }^{16}$ The list of state-owned banks was compiled from Sherif et al. (2003), Matovnikov (2002) and Mamontov (2005), and includes banks owned by the CBR as well as banks owned by other government entities or by sub-federal governments.

17 Throughout the analysis outliers, with deposit growth below the 0.5 or above the 99.5 percentile, are filtered out.
} 


\section{Methodology}

We apply a difference-in-difference estimator to identify the effect of deposit insurance on the behavior of depositors. To our knowledge, this approach has not been used to capture the impact of a financial safety net policy on market discipline. Several beneficial features of our data allow us to conduct what is in effect a natural experiment. Explicit deposit insurance was introduced in the middle of the period covered by our data. When introduced, it covered households but not firms. And the deposit holdings of these two groups are reported separately. We thus can observe the behavior of the "treated" group both before and after "treatment." And we can distinguish depositors who receive the "treatment" - i.e., explicit deposit insurance - from those that do not.

Exploiting these features of the data, a difference-in-difference specification allows us to compare the change in market discipline - before and after explicit deposit insurance among household depositors to the corresponding change among firm depositors. Comparing changes, or differencing differences, allows us to control for both time-invariant factors that affect households and firms differently and for time-varying factors that affect them in a similar fashion. The change in the disciplining behavior of firms after the introduction of deposit insurance on household deposits is an estimate of the unobserved counterfactual - i.e., what would have happened to the disciplining behavior of households if there had been no policy of explicit insurance introduced.

The difference-in-difference model can be specified in regression form as

$$
\Delta \ln \left(D_{i j t}\right)=b_{1} X_{i, t-1}+b_{2} X_{i, t-1} I+b_{3} X_{i, t-1} H+b_{4} X_{i, t-1} I H+Z+\varepsilon_{i t}
$$

with the dependent variable being the first difference of the log of deposits of type $j$ (firm or household) for bank $i$ during period $t$. Many studies of deposit market discipline also use a measure of bank deposit rates as a dependent variable to test whether depositors "demand" a rate premium from riskier banks; in light of our work demonstrating a backward-bending deposit supply curve in Russia (Karas et al., forthcoming), suggesting that the deposit rate itself may be interpreted as a measure of otherwise unobservable risk, we elect to focus on market discipline applied exclusively through quantities (i.e., deposit flows) rather than through prices as well.

The right-hand-side variables include a vector of bank-level risk factors, $X_{i, t-1}$, that varies over time and across banks. In our baseline specification, this is a measure of capitalization $\left(C_{i, t-1}\right)$; in others, we include a measure of liquidity $(L i, t-1)$.

The dummy variables, $H$ and $I$, take on the value of one if, respectively, the observation is for household deposits (as opposed to those of firms) and/or is recorded after the introduction of explicit deposit insurance in the third quarter of 2004. The coefficient $b_{4}$ is the difference-in-difference estimate of the impact of explicit deposit insurance. The vector of controls $Z$ changes across specifications. In one, $Z=\lambda_{t}+\lambda_{t} H$, where $\lambda_{t}$ is a timespecific dummy that controls for time-varying macroeconomic effects that may have a uniform impact across depositors. The inclusion of the interaction term, $\lambda_{t} H$, allows this common effect to differ depending on whether the depositor is a household or firm. 
In a second specification, $Z=\lambda_{t}+\lambda_{t} H+\mu_{i j}$, where $\mu_{i j}$ is a fixed effect to control for unobserved heterogeneity in the relationship between specific banks $(i=1 \ldots N)$ and specific depositor types ( $j=h o u s e h o l d$ or firm). Lastly, we control for lagged values of the dependent variable by setting $Z=\lambda_{t}+\lambda_{t} H+\sum_{1}^{4} a_{F l} \Delta \ln \left(D_{i, j, t-1}\right)+\sum_{1}^{4} a_{H l} \Delta \ln \left(D_{i, j, t-1}\right) H$. This allows us to distinguish the relationship between bank-level risk and market discipline from regular deposit dynamics.

\section{Results}

The results from the difference-in-difference estimations are laid out in Table 2. The specifications in columns 1-3 include controls for time-varying factors that may have a uniform impact on all depositors of a particular type (household or firm); those in columns 4-6 also include controls for bank-depositor-type fixed effects; and the models represented in columns 7-9 control for both time fixed effects and deposit dynamics in the previous four periods. In columns 1, 4 and 7, our measure of bank risk is capitalization alone; in columns 2, 5 and 8, bank risk is proxied for by liquidity alone; and in columns 3, 6 and 9, both measures are included.

\section{[Table 2]}

We observe that prior to the introduction of deposit insurance, firm's were sensitive to bank capitalization (see row 1). This result is robust to the inclusion of a variety of controls. Moreover, we observe that when controlling for time and bank fixed effects, firms became even more sensitive to capitalization after the introduction of deposit insurance in the last quarter of 2004 (see row 3, columns 4 and 6). Such an increase in sensitivity after 2004 is consistent with banking crises providing a "wake-up call," making depositors even more vigilant as to the stability of their banks (Martinez-Peria and Schmukler, 2001).

The evidence from rows 1 and 2 also suggests that households were sensitive to bank capitalization levels prior to the introduction of deposit insurance (i.e., $b_{1}+b_{2}>0$ ) but less so than firms, since we observe that $b_{2}$ is negative and statistically significant across all specifications.

Most noteworthy given our focus here, we observe in row 4 that the difference-indifference coefficient, $b_{4}$, is negative and statistically significant across all specifications but one, indicating that the relative sensitivity of households to bank capitalization diminished after the introduction of deposit insurance. This finding, which points to deposit insurance having reduced the market disciplining behavior of the insured group, is robust to the inclusion of bank-depositor-type fixed effects (see column 4) as well as the inclusion of a second measure of bank risk, liquidity (see columns 3, 6 and 9).

To visualize the temporal pattern of the difference-in-difference coefficient above, we allow the sensitivity of firms' and households' deposits to capital to be different in every time period by estimating:

$$
\Delta \ln \left(D_{i j t}\right)=b_{1, t} C_{i, t-1} \lambda_{t}+b_{3, t} C_{i, t-1} \lambda_{t} H+Z+\varepsilon_{i t}
$$


with $Z=\lambda_{t}+\lambda_{t} H+\mu_{i j}$. Figure 1 shows how the value of $b_{3}$, the relative sensitivity of household deposits drops after the introduction of deposit insurance in the third quarter of 2004 (vertical line). Figure 1 also helps show that our finding for $b_{4}$ in equation (1) is not driven exclusively by observations in the periods immediately preceding or following this date.

As to whether the negative coefficient on $b_{4}$ represents a decline in the sensitivity of households to capitalization in an absolute (and not just a relative) sense, the evidence is mixed. In the specifications presented in columns 1, 3 and 9, the decrease in sensitivity appears absolute - i.e., $\mathrm{b}_{4}$ is negative and different from zero in a statistically significant manner but $b_{3}$ is not statistically different from zero (see row 3). Specifications in columns 4 and 6, however, present a different story. They suggest that the "wake-up call effect" felt by all depositors in the aftermath of the crisis had an offsetting effect on the disciplining behavior of household depositors. The two effects work in opposite directions and roughly cancel one another out. What is clear, however, is that after deposit insurance was introduced, the sensitivity of insured households to bank risk decreased markedly relative to the sensitivity of uninsured firms.

\section{Crises, Deposit Insurance and Market Discipline}

Any conclusion to the effect that we have identified the effect of deposit insurance on market discipline rests on an assumption that during the period covered by our analysis there are no time-specific factors - with the exception of the insurance scheme's introduction - that had a differential impact on the two types of depositors. The occurrence of a banking crisis in Russia, roughly concurrent to the introduction of deposit insurance, thus gives us pause. Martinez-Peria and Schmukler (2001), for one, present evidence that crisis periods increase market discipline by providing a "wake-up call" to depositors. ${ }^{18}$ If the effect of the 2004 crisis differs across depositor types, then the difference-in-difference estimation that we have laid out above cannot disentangle the impacts of deposit insurance and the crisis on market discipline. This is a non-trivial matter for reasons that transcend our identification strategy. The introduction or expansion of deposit insurance often occurs concurrent, and indeed in response, to banking crises (Demirguc-Kunt, Kane and Laeven, 2008). ${ }^{19}$ Better understanding their interaction thus carries potential value for policy makers

\footnotetext{
${ }_{18}$ Using a large cross-country panel data set with banks from 32 countries, covering the period 19932000, Nier and Baumann (2006) show that the effect of variables associated with market disciplining behavior is greater in countries that experienced a crisis. This, they explain, may be due to bank franchise values in crisis countries being lower and risk taking incentives (in the absence of market discipline) being stronger.

${ }^{19}$ In the midst of the Great Depression, the U.S. Congress enacted the first national deposit insurance system. In the 1990s, Sweden, Japan, Thailand, Korea, Malaysia and Indonesia all introduced or expanded deposit insurance coverage (Demirguc-Kunt and Kane, 2002). The recent global crisis has given rise to a similar phenomenon.
} 
as they evaluate the costs and benefits of financial safety net expansion during periods of systemic instability.

Since we cannot rule out a priori the possibility that household depositors may react differently than firms to periods of banking crisis, we return to the Russian data and expand the temporal scope of our analysis so as to include the time period before the 1998 crisis. The data offer us, in a sense, another natural experiment. In 1998, Russian depositors were subjected to a severe banking panic but the government did not introduce deposit insurance. In 2004, as we have discussed, depositors again suffered through a banking panic, but this time a comprehensive deposit insurance scheme was introduced to cover households alone. The disciplining behavior of households and firms in the aftermath of 1998 serves as benchmark against which to compare their behaviors in the wake of the 2004 events. The noteworthy difference in the two episodes of course is the introduction of deposit insurance.

Both the absolute change of the disciplining behavior of households after the 1998 crisis and its relationship to the change in the behavior of firms serve as an estimate of the unobserved counterfactual - i.e., what would have happened to the disciplining behavior of households in a relative and absolute sense if there had been no deposit insurance introduced at roughly the same time as the banking panic of 2004. Evidence that firms responded similarly to the two panics but that households responded differently would be consistent with deposit insurance having affected the behavior of households.

To carry out what amounts to an extended robustness check of our finding in the prior section, we estimate the sensitivity of deposit flows to bank capitalization, allowing for different sensitivities across the two depositor types and three distinct periods: before the 1998 crisis, between the 1998 and the 2004 crises, and after the 2004 crisis. Specifically, we estimate:

$$
\Delta \ln \left(D_{i j t}\right)=f_{0} C_{i, t-1} F^{0}+f_{1} C_{i, t-1} F^{1}+f_{2} C_{i, t-1} F^{2}+h_{0} C_{i, t-1} H^{0}+h_{1} C_{i, t-1} H^{1}+h_{2} C_{i, t-1} H^{2}+Z+\varepsilon_{i t}
$$

As in equation (1), the dependent variable is the first difference of the log of deposits of type $j$ (firm or household) for bank $i$ during period $t$. The right-hand-side variables include a lagged measure of bank-level capitalization, $C_{i, t-1}$, that varies over time and across banks and dummies for both firm and household deposits for three specific time periods: $F^{0}=1$ and $H^{0}=1$ for firm and household deposits, respectively, before 1998q4; $F^{1}=1$ and $H^{1}=1$ for firm and household deposits, respectively, for the period between 1998q4 - 2004q3; and $F^{2}=1$ and $H^{2}=1$ for firm and household deposits, respectively, after 2004q3.

As above, in our first specification, $Z=\lambda_{t}+\lambda_{t} H$, where $\lambda_{t}$ is a time-specific dummy that controls for time-varying macroeconomic effects that have a uniform impact across depositors. The inclusion of the interaction term, $\lambda_{t} H$, allows this effect to differ for households and firms. In a second specification, $Z=\lambda_{t}+\lambda_{t} H+\mu_{i j}$, where $\mu_{i j}$ is a fixed effect included to control for unobserved time-invariant heterogeneity in the relationship between specific banks $(i=1 \ldots N)$ and specific depositor types ( $j=$ household or firm).

\section{[Table 3]}


Panel A of Table 3 reports the estimation results both exclusive and inclusive of bank-depositor-type fixed effects (columns 1 and 2, respectively). In Panel B, coefficient tests present comparisons of market discipline across time and depositor types.

We observe from rows 1-3 of Panel A that firms were sensitive to bank risk across each sub-period; coefficient estimates are consistently positive and statistically significant. And in line with the "wake-up call" hypothesis, the degree of this sensitivity increased in the period after each crisis. For instance, when controlling for both time and bankdepositor-type fixed effects, we observe that $f_{1}$ is greater than $f_{0}$ (Panel $B$, row 1 ) and $f_{2}$ is greater than $f_{1}$ (Panel B, row 4). Using this same specification, we do not observe a statistically significant difference in the changes in firms' disciplining behavior in the wake of the two crises (Panel B, row 6).

Unlike firms, we find no evidence that households were sensitive to bank risk prior to the 1998 crisis but, like firms, they displayed such sensitivity in its aftermath (Panel A, row 5). In row 3 of Panel $B$, we test the hypothesis that the change in disciplining behavior was the same for households and firms after the 1998 crisis. The results show that we cannot dismiss this possibility. The evidence, in other words, is consistent with the first crisis having served as a "wake-up call" for both depositor types.

Again referring to the specification with bank-depositor-type fixed effects, after the 2004 crisis, household sensitivity to bank capitalization did not change (Panel B, row 5). And whereas the behavior of firms in the aftermath of the two crises was not dissimilar (Panel B, row 6), the reaction of households demonstrably was (Panel B, row 7). And perhaps most clearly, we can reject the hypothesis that the sensitivity of households and firms to bank capitalization changed in a similar fashion after 2004 (Panel B, row 8), a result that holds whether or not we control for bank-depositor-type fixed effects.

In sum, this extended robustness check presents evidence that suggests that the change in the relative disciplining behaviors of firms and households after 2004 was not due to their responding differently to the banking crisis. We found the relative sensitivity of household and firm deposit flows to bank capitalization rose in an identical manner after the 1998 crisis. After the 2004 crisis, the relative sensitivity of uninsured firm deposit flows to bank capitalization rose again markedly and in a manner not dissimilar to the change after the 1998 crisis. The sensitivity of insured household deposit flows to bank capitalization however remained unchanged or even fell after 2004. The early crisis had a similar effect on the two groups; the latter crisis did not. We interpret this evidence as confirming the negative impact of deposit insurance on market discipline.

\section{Conclusion}

By employing data from a natural experiment in Russia, we provide the cleanest test of deposit insurance's effect on market discipline in the literature. We employ a differencein-difference estimator to identify the differential effect of deposit insurance on the behavior of insured versus uninsured depositors and find evidence consistent with insurance diminishing the sensitivity to bank risk. By comparing the relationship of risk 
sensitivity across depositor types and multiple banking crises, we feel confident in dismissing the possibility that our results might be explained by a different reaction of households and firms to a banking crisis that hit at roughly the same time as the insurance scheme was introduced.

Importantly, our findings demonstrate the potential for deposit insurance to increase moral hazard behavior among banks. Moreover, they speak to the interaction of deposit insurance and crises on market discipline. Uninsured depositors respond to a crisis by increasing market discipline, thereby providing a potentially valuable check to banks contemplating the assumption of even more risk during a period of systemic instability. While we do not claim that newly insured depositors will be entirely numb to bank risk in the aftermath of a crisis, the market discipline they impose will clearly be less vigorous than that of uninsured groups. Our results thus might be interpreted to suggest that policy makers exercise caution with respect to any crisis-related expansion of deposit insurance lest incentives for already weak banks to gamble for resurrection be strengthened. 


\section{Sources Cited}

Barth, James, Gerard Caprio and Ross Levine, 2006. Rethinking Bank Regulation: Till Angels Govern. New York: Cambridge University Press.

Barth, James, Gerard Caprio and Ross Levine, 2004. "Bank Regulation and Supervision: What Works Best?" Journal of Financial Intermediation 13, 205-248.

Calomiris, Charles, 1999. “Building an Incentive-compatible Safety Net," Journal of Banking and Finance 23, 1499-1519.

Camara, Modibo and Fernando Montes-Negret, 2006. “Deposit Insurance and Banking Reform in Russia," World Bank WPS 4056.

Chernykh, Lucy and Rebel Cole, 2008. "Does Deposit Insurance Improve Financial Intermediation? Evidence from the Russian Experiment," http://ssrn.com/abstract=1328444.

Cook, Douglas and Louis Spellman, 1994. "Repudiation Risk and Restitution Costs: Toward Understanding Premiums on Insured Deposits," Journal of Money, Credit and Banking 26, 439459 .

Demirguc-Kunt, Asli and Enrica Detragiache, 2002. "Does Deposit Insurance Increase Banking System Stability? An Empirical Investigation," Journal of Monetary Economics 49, 1373-1406.

Demirguc-Kunt, Asli and Harry Huizinga, 2004, "Market Discipline and Deposit Insurance," Journal of Monetary Economics 51, 375-399.

Demirguc-Kunt, Asli and Edward Kane, 2002. “Deposit Insurance around the Globe: Where Does It Work?" Journal of Economic Perspectives 16, 175-195.

Flannery, Mark J., and Sorin M. Sorescu, 1996. "Evidence of Bank Market Discipline in Subordinated Debenture Yields: 1983-1991," Journal of Finance 51 1347-1377.

Gropp, Reint and Jukka Vesala, 2004. “Deposit Insurance, Moral Hazard and Market Monitoring," Review of Finance 8, 571-602.

Ioannidou, Vasso and Jan de Dreu, 2006. “The Impact of Explicit Deposit Insurance on Market Discipline," http://papers.ssrn.com/abstract_id=888681.

Kane, Edward, 1989. The S\&L Insurance Mess: How Did It Happen? Urban Institute Press, Washington, DC.

Karas, Alexei, William Pyle and Koen Schoors, forthcoming. "How Do Russian Depositors Discipline Their Banks? Evidence of a Backward Bending Deposit Supply Function," Oxford Economic Papers.

Karas, Alexei and Koen Schoors, 2005. "Heracles or Sisyphus? Finding, Cleaning and Reconstructing a Database of Russian Banks," Ghent University Working Paper 05/327.

Mamontov, A., 2005. “Gosudarstvo v Bankakh: Zlo ili Blago?" Natsional'nyi Bankovskii Zhurnal 12, 24. 
Martinez-Peria, Maria and Sergio Schmukler, 2001. “Do Depositors Punish Banks for Bad Behavior? Market Discipline, Deposit Insurance, and Banking Crises." Journal of Finance 56, 1029-1051.

Matovnikov, Mikhail, 2002. “Nadezhnost' Banka Tesno Svyazana so Strukturoi ego Aktsionernogo Kapitala." Tsentr Ekonomicheskogo Analiza-Interfax, Moscow.

Merton, Robert, 1977. An Analytic Derivation of the Cost of Deposit Insurance Loan Guarantees." Journal of Banking and Finance 1, 3-11.

Nier, Erlend and Ursel Baumann, 2006. "Market Discipline, Disclosure and Moral Hazard in Banking," Journal of Financial Intermediation 15, 332-361.

Park, Sangkyun and Stavros Peristiani, 1998. “Market Discipline by Thrift Depositors," Journal of Money, Credit and Banking 30, 347-364.

Peresetsky, Anatoly, 2008. "Market Discipline and Deposit Insurance in Russia," BOFIT Discussion Paper 14.

Radaev, Vadim, 2000. "Return of the Crowds and Rationality of Action: A History of Russian Financial Bubbles in the Mid-1990s," European Societies 2, 271-294.

Schoors, Koen, 2001. “The Credit Squeeze during Russia's Early Transition: A Bank-based View," Economics of Transition 9, 205-228.

Sherif, Khaled, Michael Borish and Alexandra Gross, 2003. State-owned Banks in the Transition: Origins, Evolution and Policy Responses. World Bank, Washington, D.C.

Spicer, Andrew and William Pyle, 2002. "Institutions and the Vicious Circle of Distrust in the Russian Household Deposit Market, 1992-1999." In Advances in Strategic Management: The New Institutionalism in Strategic Management, edited by Paul Ingram and Brian Silverman, pp. 371-396. New York: JAI Press.

Tompson, William, 2004. Banking Reform in Russia: Problems and Prospects. OECD Economics Working Paper \#410.

Ungan, Ece, Selcuk Caner and Suheyla Ozyildirim, 2008. "Depositors' Assessment of Bank Riskiness in the Russian Federation," Journal of Financial Services Research 33, 77-110.

Van Soest, Arthur, Anatoly Peresetsky and Alexander Karminsky. 2003. "An analysis of ratings of Russian banks." Discussion Paper 85, Tilburg University, Center for Economic Research.

“What Deposit Rate Do Russians Consider Acceptable?" ("Kakuiu protsentnuiu stavku po vkladam rossiianie schitaiut priemlemoi?"), 2008. Press release 28, March 25. National Agency for Financial Research. http://nacfin.ru/novosti-i-analitika/press/press/single/9888.html. 
Table 1. Summary statistics

$1999 q 1-2004 q 2$

Firm deposit growth

Household deposit growth

Firm deposits / Assets

Household deposits / Assets

Capital / Assets

Liquid assets / Demand liabilities

2004q3 - 2007q1

Firm deposit growth

Household deposit growth

Firm deposits / Assets

Household deposits / Assets

Capital / Assets

Liquid assets / Demand liabilities

\section{Mean}

0.10

0.13

0.35

0.13

0.30

0.81

0.09

0.12

0.36

0.25

0.23

0.66
Std. dev.

0.54

0.50

0.20

0.13

0.22

1.22

0.43

0.36

0.18

0.18

0.16

0.94
Min

$-2.59$

$-3.15$

0.00

0.00

$-1.00$

0.00

$-2.55$

$-3.19$

0.00

0.00

0.03

0.00

3.25

3.82

0.95

0.87

1.00

10.00 
Table 2. Determinants of household and firm deposit flows

$\mathrm{Z}=\lambda_{\mathrm{t}}+\lambda_{\mathrm{t}} H$

(1)

$\begin{array}{lc}\text { (1) } \mathrm{C}_{\mathrm{i}, \mathrm{t}-1} & \begin{array}{c}0.34^{\star \star \star} \\ (0.03)\end{array} \\ \text { (2) } \mathrm{C}_{\mathrm{i}, \mathrm{t}-1} \mathrm{H} & -0.23^{\star \star \star} \\ & (0.04) \\ \text { (3) } \mathrm{C}_{\mathrm{i}, \mathrm{t}-\mathrm{l}} \mathrm{I} & 0.06 \\ & (0.05) \\ \text { (4) } \mathrm{C}_{\mathrm{i}, \mathrm{t}-1} \mathrm{IH} & -0.18^{\star \star} \\ \text { (5) } \mathrm{L}_{\mathrm{i}, \mathrm{t}-1} & (0.08)\end{array}$

(6) $\mathrm{L}_{\mathrm{i}, \mathrm{t}-1} \mathrm{H}$

(7) $\mathrm{L}_{\mathrm{i}, \mathrm{t}-\mathrm{l}} \mathrm{l}$

(8) $L_{i, t-1} 1 H$

R-squared
(2)

$\begin{array}{cc}(3) & (4) \\ 0.30^{\star \star \star} & 0.62^{\star \star \star} \\ (0.03) & (0.05) \\ 0.21^{\star \star \star} & -0.44^{\star \star \star} \\ (0.04) & (0.06) \\ 0.08 & 0.25^{\star \star \star} \\ (0.05) & (0.06) \\ -0.19^{\star \star} & -0.20^{\star \star} \\ (0.07) & (0.08) \\ 0.02^{\star \star \star} & \\ (0.01) & \\ -0.01 & \\ (0.01) & \\ -0.02 & \\ (0.02) & \\ 0.01 & \\ (0.02) & \\ 54803 & 54934 \\ 0.034 & 0.041\end{array}$

$$
Z=\lambda_{t}+\lambda_{t} H+\mu_{i j}
$$

(5)

$\begin{array}{cc} & 0.58^{\star \star \star} \\ & (0.05) \\ & -0.42^{\star \star \star} \\ & (0.06) \\ & 0.29 * \star \star \\ & (0.06) \\ & -0.24^{\star \star \star} \\ & (0.08) \\ & 0.03^{\star \star \star} \\ & (0.01) \\ 0.05^{\star \star \star} & -0.01 \\ (0.01) & (0.01) \\ -0.02^{\star} & -0.03 \\ (0.01) & (0.02) \\ & \\ -0.00 & 0.02 \\ (0.01) & (0.03) \\ 0.01 & \\ (0.02) & 54803 \\ & 0.042 \\ 54819 & \end{array}$

$$
Z=\lambda_{t}+\lambda_{t} H+\sum_{1}^{4} a_{F l} \Delta \ln \left(D_{i, j, t-1}\right)+\sum_{1}^{4} a_{H l} \Delta \ln \left(D_{i, j, t-1}\right) H
$$

(7)

$0.20^{\text {*** }}$

(0.03)

$-0.13^{\star \star *}$

(0.04)

0.01

(0.06)

$-0.10$

(0.08)
(8)

(9)

0.19 ***

(0.03)

$-0.12^{\text {*** }}$

(0.04)

0.04

(0.06)

$-0.15^{*}$

(0.08)

0.01

(0.01)

$-0.01$

(0.01)

$-0.02$

(0.02)

0.03

(0.03)

44799 
Figure 1: Sensitivity of household deposits to bank capitalization relative to sensitivity of firm deposits to capital (i.e., coefficient $b_{3}$ ) over time

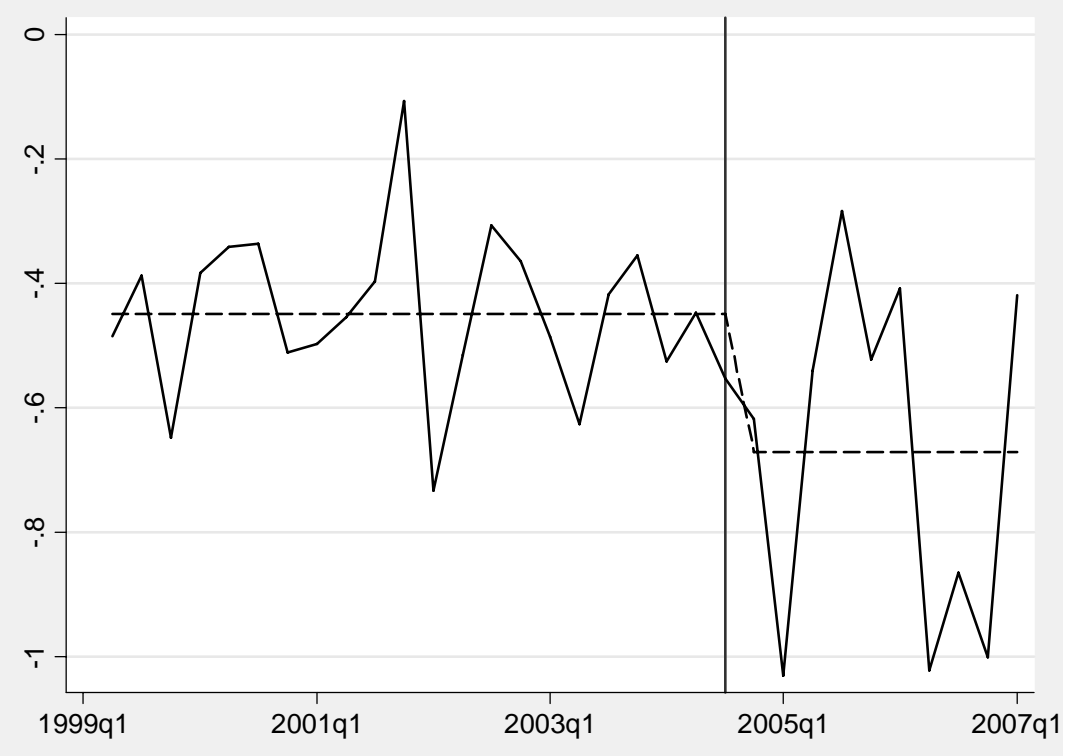


Table 3. Crises and the sensitivity of deposits to bank capitalization

Panel A. Estimation results for equation (3)

Firm deposit flows

Variables in (2)

(1) $1995 q 4-1998 q^{3}$

(2) $1998 q 4-2004 q 3$

(3) $2004 q 4-2007 q 1$

Household deposit flows

(4) $1995 q 4-1998 q^{3}$

(5) $1998 q 4-2004 q 3$

(6) $2004 q 4-2007 q 1$

Observations

R-squared

Robust standard errors in parentheses; ${ }^{* *} p<0.01,{ }^{* *} p<0.05,{ }^{*} p<0.1$

Panel B. Hypothesis tests on coefficients in equation (3)

(1) Sensitivity of firm deposits to capitalization pre- and post-first crisis: $f_{1}-f_{0}=0$.

(2) Sensitivity of household deposits to capitalization pre- and postfirst crisis: $h_{1}-h_{0}=0$

(3) Relative sensitivity of household and firm deposits to first crisis: $\left(h_{1}-h_{0}\right)-\left(f_{1}-f_{0}\right)=0$

(4) Sensitivity of firm deposits to capitalization pre- and post-second crisis: $f_{2}-f_{1}=0$

(5) Sensitivity of household deposits to capitalization pre- and postsecond crisis: $\mathrm{h}_{2}-\mathrm{h}_{1}=0$

(6) Relative sensitivity of firm deposits to first and second crisis:

$\left(f_{2}-f_{1}\right)-\left(f_{1}-f_{0}\right)=0$

(7) Relative sensitivity of household deposits to first and second crisis: $\left(\mathrm{h}_{2}-\mathrm{h}_{1}\right)-\left(\mathrm{h}_{1}-\mathrm{h}_{0}\right)=0$

(8) Relative sensitivity of household and firm deposits to first crisis: $\left(\mathrm{h}_{2}-\mathrm{h}_{1}\right)-\left(\mathrm{f}_{2}-\mathrm{f}_{1}\right)=0$

$p$-values in parentheses

$\begin{array}{cc}\mathrm{Z}=\lambda_{\mathrm{t}}+\lambda_{\mathrm{t}} H & \mathrm{Z}=\lambda_{t}+\lambda_{t} H+\mu_{i j} \\ 0.18^{\star \star \star} & 0.38^{\star \star \star} \\ (0.03) & (0.05) \\ 0.36^{\star \star \star} & 0.60^{\star \star \star} \\ (0.03) & (0.04) \\ & \\ 0.40^{\star \star \star} & 0.80^{\star \star \star} \\ (0.05) & (0.06) \\ & \\ -0.04 & -0.05 \\ (0.03) & (0.05) \\ 0.14^{\star \star *} & 0.22^{\star \star \star} \\ (0.02) & (0.03) \\ -0.01 & 0.20^{\star \star *} \\ (0.05) & (0.06) \\ 77678 & 77678 \\ 0.042 & 0.046\end{array}$

$\begin{array}{cc}Z=\lambda_{t}+\lambda_{t} H & Z=\lambda_{t}+\lambda_{t} H+\mu_{i j} \\ 0.18 & 0.22 \\ (0.00) & (0.00) \\ & \\ 0.18 & 0.27 \\ (0.00) & (0.00) \\ & \\ -0.01 & 0.05 \\ (0.92) & (0.50) \\ & \\ 0.04 & 0.20 \\ (0.47) & (0.00) \\ & \\ -0.15 & -0.02 \\ (0.01) & (0.78) \\ & \\ -0.14 & -0.02 \\ (0.05) & (0.80) \\ & \\ -0.32 & -0.29 \\ (0.00) & (0.00) \\ & \\ -0.18 & -0.21 \\ (0.02) & (0.01) \\ & \end{array}$

